\title{
Research on energy consumption evaluation methods for production process of large transit crude oil depot in alpine region
}

\author{
Lin Yang $^{1 \text {, a }}$, Lixin $\mathrm{Wei}^{1}$, Xinyang $\mathrm{Li}^{1}$, Lina Shan ${ }^{1}$, Jiyang Zou ${ }^{1}$ \\ ${ }^{1}$ Oil and Gas transportation and storage department, Northeast petroleum university, Daqing, \\ 163318, China \\ aemail: soulkissing@163.com
}

Keywords: crude oil storage; energy consumption evaluation; energy efficiency; alpine region

\begin{abstract}
According to the production process characteristics of transit crude oil depot, the evaluation model for the major energy-using equipment in crude oil depot was established. According to the law for energy conservation and transformation, the energy balance equation for crude oil depot was established. Six evaluation energy level depot indicators, including the energy efficiency, heat energy efficiency, electricity energy efficiency, power consumption for the transport of unit oil, and gas consumption for the transport of unit oil, the comprehensive energy consumption for the transport of unit oil were proposed. On the basis, the energy using status for a transit crude oil depot in the oil filed was evaluated. The result shows that, the overall energy utilization level of transit crude oil storage can be reflected by energy efficiency. The energy efficiency analysis for crude oil storage is helpful to determine the energy weaknesses and is contribute to point out the direction to improve the energy level.
\end{abstract}

\section{Introduction}

Crude oil transit unit depot is the heart of oil production. Meanwhile, it is the center unit of output and storage of crude oil. In general, the crude oil storage is abundance, the energy-using equipment and energy consumption are very large. Particularly for large oil depot alpine region.However,its dimension warm winter consumption is very impressive. How can reasonably control the oil reservoir of energy consumption and how to improve its operating efficiency is an important issue that concerned by researchers in the field of crude oil storage and transportation. In order to achieve this goal, the premise is to accurately grasp the energy levels of crude depot ,and to determine their energy weakness .At present, some scholars to carry out research on energy consumption of crude oil depot, Zhou Hailian[1] use the process simulation systems theory for crude oil storage and transportation system parameter simulation, using thermodynamic analysis method based on this depot for crude energy evaluation and analysis .Yu Tao adopted [2] "three-box" model based on thermodynamics, with $\mathrm{C}++$ Builder programming language developed a calculation program depot system energy analysis of the energy process depot a preliminary analysis .Liu Erheng [3] to establish a thermal storage tank, into the pot of oil brought into sensible heat, among external heat source-dimensional mathematical model of heat transfer and temperature correlation System thermal load obtained by oil minimum allowable maximum storage temperature affect the conclusions on this basis, summarized the critical process parameters to optimize storage and transportation systems Simple Graphical design methods and optimization of energy measures. In the depot steam pipe network system and the heat medium heater system as the research object, oil depot energy consumption is the objective to establish the corresponding mathematical model, through its optimization method established can obtain crude oil storehouse energy consumption lowest operating mode by Li Dehai [4].In addition, there are some scholars try [5-7] from the heating temperature of the crude oil reservoirs, storage tanks and pipelines temperature insulation angles analyze energy consumption of crude oil depot, the operational plan for optimization studies. Although some researchers carried out the energy consumption of crude oil, most depots concerned that long-term storage of crude oil state. As the crude oil transit depot, since they tend to run in a non-steady state process receive oil. So their energy analysis will be more complex. Nevertheless, 
energy analysis in alpine regions crude oil reservoir to enhance oil production efficiency, reduce energy consumption makes sense. Therefore, this paper major transit depot alpine region in this study. It is based on the energy balance and conversion model, a depot of crude oil transit energy evaluation method of forming a depot of crude energy level analysis.

\section{Mathematical mode}

\section{Analysis of energy transfer process}

For energy process, to send and receive process oil depot of the Central Plains depending on the system model can be classified into the energy transfer process, the process of energy conversion and energy utilization processes. For different energy process, according to its nature characteristics, it can be performed by specific indicators of its energy level evaluation, from the depot unit process point of view of energy use efficiency can reflects the crude oil. The major energy transit depot for equipment in the process can be summarized as follows:

Table 1 transit depot can process equipment energy use

\begin{tabular}{|c|c|c|c|c|c|}
\hline $\begin{array}{c}\text { Energy-consuming } \\
\text { equipment }\end{array}$ & Crafting process & $\begin{array}{c}\text { Energy } \\
\text { process type }\end{array}$ & Input Energy & $\begin{array}{r}\text { Energy } \\
\text { output }\end{array}$ & Main index \\
\hline Furnace & Crude oil heating & $\begin{array}{c}\text { Energy } \\
\text { Conversion }\end{array}$ & $\begin{array}{c}\text { Fuel chemical } \\
\text { energy }\end{array}$ & Heat & $\begin{array}{l}\text { Thermal efficiency } \\
\text { Energy efficiency }\end{array}$ \\
\hline Boiler & $\begin{array}{c}\text { Provide hot } \\
\text { vapor }\end{array}$ & $\begin{array}{c}\text { Energy } \\
\text { Conversion }\end{array}$ & $\begin{array}{c}\text { Fuel chemical } \\
\text { energy }\end{array}$ & Heat & $\begin{array}{l}\text { Boiler efficiency } \\
\text { Energy efficiency }\end{array}$ \\
\hline Transport-oil Pump & Crude oil booster & $\begin{array}{c}\text { Energy } \\
\text { Conversion }\end{array}$ & Electricity & $\begin{array}{c}\text { Pressure } \\
\text { energy }\end{array}$ & Pump efficiency \\
\hline Heat Exchanger & $\begin{array}{c}\text { Heating } \\
\text { circulating hot } \\
\text { oil }\end{array}$ & $\begin{array}{l}\text { Energy } \\
\text { transfer }\end{array}$ & Steam heat & $\begin{array}{c}\text { Oil of } \\
\text { thermal } \\
\text { energy }\end{array}$ & $\begin{array}{l}\text { Heat transfer } \\
\text { efficiency }\end{array}$ \\
\hline Oil Pipeline & $\begin{array}{l}\text { Transportation of } \\
\text { crude oil }\end{array}$ & $\begin{array}{l}\text { Energy } \\
\text { transfer }\end{array}$ & $\begin{array}{l}\text { Crude oil heat, } \\
\text { pressure energy }\end{array}$ & $\begin{array}{c}\text { Crude oil } \\
\text { heat, pressure } \\
\text { energy }\end{array}$ & $\begin{array}{c}\text { Transmission } \\
\text { efficiency } \\
\text { Utilization of } \\
\text { geothermal energy } \\
\text { Power utilization }\end{array}$ \\
\hline Steam pipe & Transport vapor & $\begin{array}{l}\text { Energy } \\
\text { transfer }\end{array}$ & $\begin{array}{l}\text { Crude oil heat, } \\
\text { pressure energy }\end{array}$ & $\begin{array}{l}\text { Crude oil } \\
\text { heat, pressure } \\
\text { energy }\end{array}$ & $\begin{array}{c}\text { Transmission } \\
\text { efficiency } \\
\text { Utilization of } \\
\text { geothermal energy } \\
\text { Power utilization }\end{array}$ \\
\hline Hot water pipes & Conveying water & $\begin{array}{l}\text { Energy } \\
\text { transfer }\end{array}$ & $\begin{array}{l}\text { Hot water heat, } \\
\text { pressure energy }\end{array}$ & $\begin{array}{l}\text { Hot water } \\
\text { heat, pressure } \\
\text { energy }\end{array}$ & $\begin{array}{c}\text { Transmission } \\
\text { efficiency } \\
\text { Utilization of } \\
\text { geothermal energy } \\
\text { Power utilization }\end{array}$ \\
\hline Oil tank & $\begin{array}{l}\text { Storage of crude } \\
\text { oil }\end{array}$ & Energy using & $\begin{array}{l}\text { Circulating hot } \\
\text { oil energy }\end{array}$ & $\begin{array}{l}\text { Oil of } \\
\text { thermal } \\
\text { energy }\end{array}$ & Heat Loss \\
\hline
\end{tabular}

\section{Energy balance model}

Energy balance approach is fundamental to the overall energy level of the evaluation system, focusing on the analysis system input is the output of the energy balance in the number, then grasp the system's energy situation, to understand the system of energy levels to determine energy-saving system energy saving potential and direction. According to the law of conservation of energy and conversion, the depot of crude oil transit energy balance equation is created as follows:

$$
\begin{gathered}
E_{\text {Sin }}+E_{S}=E_{\text {Sout }}+\triangle E_{S} \\
E_{\text {Sin }}=E_{\text {Shin }}+E_{\text {Spin }} \\
E_{S}=E_{S h}+E_{S e}
\end{gathered}
$$




$$
\begin{gathered}
E_{\text {Sout }}=E_{\text {Shout }}+E_{\text {Spout }} \\
\triangle E_{S}=\triangle E_{S h}+\triangle E_{S p}
\end{gathered}
$$

Where: $E_{\mathrm{Sin}}$ is the total energy of the medium into the crude oil into the depot, including the media and the pressure energy into thermal energy, $\mathrm{kJ} / \mathrm{h} ; E_{\mathrm{S}}$ is the total energy supplied to the outside world crude oil depot, including electricity and heat, $\mathrm{kJ} / \mathrm{h} ; E_{\mathrm{Sout}}$ is the total energy out of media left when crude oil depot, including thermal and pressure energy, $\mathrm{kJ} / \mathrm{h} ; \Delta E_{\mathrm{S}}$ is the total energy of petroleum storage depots losses, including the loss of heat and pressure energy loss, $\mathrm{kJ} / \mathrm{h}$; $E_{\text {Shin }}$ : When crude oil into the media depot with respect to the reference temperature into thermal energy, $\mathrm{kJ} / \mathrm{h} ; E_{\mathrm{Spin}}$ : When crude oil into the media depot with respect to the reference pressure into pressure energy, $\mathrm{kJ} / \mathrm{h} ; E_{\mathrm{Sh}}$ : For the supply of crude oil outside the depot heat, $\mathrm{kJ} / \mathrm{h} ; E_{\mathrm{Sp}}$ : For the supply of crude oil outside the depot energy, $\mathrm{kJ} / \mathrm{h} ; E_{\text {Shout }}$ : Crude oil output media depot with respect to the reference temperature of thermal energy brought out, $\mathrm{kJ} / \mathrm{h} ; E_{\text {Spout }}$ : is the output media depot reference pressure relative to the pressure can bring out, $\mathrm{kJ} / \mathrm{h} ; \Delta E_{\mathrm{Sh}}$ : is the total heat loss of crude oil depot, $\mathrm{kJ} / \mathrm{h} ; \Delta E_{\mathrm{Sp}}$ : is the total heat loss of crude oil depot, $\mathrm{kJ} / \mathrm{h}$.

\section{Consumption index}

According to the energy balance equation, the power consumption evaluation is established:

(1) Petroleum storage depots energy efficiency

$$
\begin{gathered}
\eta_{S}=\frac{E_{\text {Sout }}}{E_{\text {Sin }}+E_{S}} \times 100 \%=\frac{E_{\text {Shout }}+E_{\text {Spout }}}{E_{\text {Shin }}+E_{\text {Spin }}+E_{\text {Sh }}+E_{\text {Se }}} \times 100 \% \\
E_{\text {Shin }}=Q_{\text {Sin }} \rho_{\text {Sin }} c_{\text {Sin }}\left(t_{\text {Sin }}-t_{0}\right) \\
E_{\text {Spin }}=Q_{\text {Sin }} p_{\text {Sin }} \times 10^{3} \\
E_{\text {Shout }}=Q_{\text {Sout }} \rho_{\text {Sout }} C_{\text {Sout }}\left(t_{\text {Sout }}-t_{0}\right) \\
E_{\text {Spout }}=Q_{\text {Sout }} p_{\text {Sout }} \times 10^{3} \\
E_{\text {Sh }}=B_{\text {Sg }} Q_{\text {net }, \text {, ar }} \\
E_{\text {Se }}=3600 N_{\text {Se }}
\end{gathered}
$$

Where: $\eta_{S}$ is the depot energy utilization, \%; $Q_{\operatorname{Sin}}$ the flow of crude oil into the media depot, $\mathrm{m} 3 / \mathrm{h} ; \rho_{\mathrm{Sin}}$ is the density of crude oil transported into the depot, $\mathrm{kg} / \mathrm{m} 3 ; c_{\mathrm{Sin}}$ is the specific heat of capacity crude oil transported into the depot, $\mathrm{kJ} /\left(\mathrm{kg} \quad{ }^{\circ} \mathrm{G}_{\mathrm{Sin}}\right.$ is the temperature of crude oil inlet the depot, ${ }^{\circ} \mathrm{C} ; p_{\operatorname{Sin}}$ is the pressure of crude oil inlet the depot, MPa; $Q_{\text {sout }}$ is the output of crude oil outside the depot, m3/h; $\rho_{\text {Sout }}$ is the density of crude oil outside the depot, $\mathrm{kg} / \mathrm{m} 3 ; c_{\text {Sout }}$ is the specific heat of crude oil outside the depot, $\mathrm{kJ} /\left(\mathrm{kg}{ }^{\circ} \mathrm{G}_{\text {Sout }}\right.$ is the temperature of crude oil outside the depot, ${ }^{\circ} \mathrm{C} ; p_{\text {Sout }}$ is the pressure of crude oil outside the depot, $\mathrm{MPa} ; \mathrm{B}_{\mathrm{Sg}}$ is the gas consumption of petroleum storage depots used as fuel, m3/h; $Q_{\text {net,v,ar }}$ is the low calorific value of gas, $\mathrm{kJ} / \mathrm{m} 3 ; N_{\mathrm{Se}}$ is the power consumption of crude oil depot, $\mathrm{kW} \cdot \mathrm{h} ; t_{0}$ is the reference temperature, ${ }^{\circ} \mathrm{C}$.

(2) Petroleum storage depots utilization of geothermal energy 


$$
\eta_{\text {Sh }}=\frac{E_{\text {Shout }}}{E_{\text {Shin }}+E_{\text {Sh }}} \times 100 \%
$$

Where: $\eta_{\mathrm{Sh}}$ is the utilization of geothermal energy depot, \%.

(3) Ppetroleum storage depots power utilization

$$
\eta_{S p}=\frac{E_{\text {Spout }}}{E_{\text {Spin }}+E_{\text {Se }}} \times 100 \%
$$

Where: $\eta_{\mathrm{sp}}$ is the depot power utilization, \%.

(4) Crude oil pool unit output power consumption postal turnover

$$
\begin{gathered}
M_{e}=\frac{N_{S e}}{W_{t}} \\
W_{t}=G_{\text {Sout }} \times 10^{-4}
\end{gathered}
$$

Where: $M_{\mathrm{e}}$ is turnover in units of oil power consumption, $\mathrm{kW} \cdot \mathrm{h} /\left(10^{4} \mathrm{t}\right) ; W_{\mathrm{t}}$ is the turnover for the oil, $10^{4} \mathrm{t} / \mathrm{h} ; G_{\text {Sout }}$ is the crude oil output capacity, t/h.

(5) units of oil consumption turnover

$$
M_{g}=\frac{B_{S g}}{W_{t}}
$$

Where: $M_{g}$ is the turnover in units of oil consumption, $\mathrm{m}^{3} /\left(10^{4} \mathrm{t}\right)$; $\mathrm{B}_{\mathrm{sg}}$ is the gas consumption of depot, $\mathrm{m}^{3} / \mathrm{h}$

(6) oil turn over unit comprehensive energy consumption

$$
M_{c}=M_{g} \cdot p_{g}+M_{e} \bullet p_{e}
$$

Where, $M_{\mathrm{g}}$ is the units of oil turnover comprehensive energy consumption, kgce/(104t); $p_{\mathrm{g}}$ is the conversion of coal to gas consumption coefficient, $\mathrm{kgce} / \mathrm{m}^{3} ; p_{\mathrm{e}}$ is the conversion of coal to power factor, kgce/kWh.

\section{Calculation Example}

\section{Research Target}

An oil depot belonging to a transit depot which located in northeastern China, it's average annual temperature is $2{ }^{\circ} \mathrm{C}$ and the winter minimum temperature can reach $-30{ }^{\circ} \mathrm{C}$.The depot's main production facilities include: a pumping station out of the transmission, four pumps centrifugal pump of KDY550-75 $\times 4$, two heat pumps for heating of circulating hot oil of 300S90; a room of measurement, a boiler room, three heating furnace of ZKJ2000-Yg / 6.4-Q which is responsible for external input heating oil specifically. The depot uses packet parallel operation and eight steel floating roof tanks $2 \times 10^{4} \mathrm{~m}^{3}$ for a seat 2 stand $5 \times 10^{4} \mathrm{~m}^{3}$ storage tanks for the one, two oil storage tanks transceiver alternately. External input pipeline specifications for $\Phi 529 \times 8 \mathrm{~mm}$ and the 0 length is $43000 \mathrm{~m}$.

\section{Operating parameters}

Field test the operating parameters of the fuel depot at different times, including the oil depot receives and outside the transmission of temperature, pressure and tank operating parameters, the ambient temperature during the test was $-18.9^{\circ} \mathrm{C}$, resulting specific operating parameters in the following table: 
Table. 2 Crude depot operating parameters

\begin{tabular}{|c|c|c|c|c|c|c|}
\hline \multirow{2}{*}{ Business units } & \multirow[t]{2}{*}{ Time } & Temperature & $\begin{array}{c}\text { Moisture } \\
\text { content }\end{array}$ & Density & Pressure & \multirow{2}{*}{$\begin{array}{c}\text { Transmission } \\
\text { capacity } \\
\mathrm{m}^{3}\end{array}$} \\
\hline & & ${ }^{\circ} \mathrm{C}$ & $\%$ & $\mathrm{~kg} / \mathrm{m}^{3}$ & MPa & \\
\hline \multirow{3}{*}{ Source oil 1} & 16 日 8:00-16:00 & 59 & 0.26 & 871 & 0.1 & 4330 \\
\hline & $\begin{array}{c}16 \text { 日 } \\
16: 00-24: 00\end{array}$ & 59 & 0.26 & 870 & 0.1 & 4250 \\
\hline & 17 日 0:00- 8:00 & 59 & 0.26 & 870.2 & 0.15 & 4214 \\
\hline \multirow{3}{*}{ Source oil 2} & 16 日 8:00-16:00 & 47 & 0.28 & 865.3 & 0.1 & 4443 \\
\hline & $16: 00-24: 00$ & 47 & 0.27 & 866.8 & 0.1 & 4446 \\
\hline & 17 日 0:00- 8:00 & 47 & 0.27 & 866.8 & 0.15 & 4373 \\
\hline \multirow{3}{*}{$\begin{array}{l}\text { External } \\
\text { input1 }\end{array}$} & 16 日 8:00-16:00 & 47.5 & 0.24 & 867.6 & 2.33 & 7484.15 \\
\hline & $16: 00-24: 00$ & 47.25 & 0.27 & 868.2 & 2.31 & 7527.06 \\
\hline & 17 日 0:00- 8:00 & 48.25 & 0.26 & 868.2 & 2.29 & 7563.49 \\
\hline \multirow{3}{*}{$\begin{array}{l}\text { External } \\
\text { input2 }\end{array}$} & 16 日 8:00-16:00 & 48 & 1.55 & 867.6 & 1.55 & 841.38 \\
\hline & $16: 00-24: 00$ & 48 & 1.55 & 868.2 & 1.55 & 818.37 \\
\hline & 17 日 0:00- 8:00 & 48 & 1.55 & 868.2 & 1.55 & 829.37 \\
\hline
\end{tabular}

Table. 3 tanks operating parameters

\begin{tabular}{c|c|c|c|c}
\hline Tank labels & Time & Level $\mathrm{m}$ & Inventories $\mathrm{O}$ & Outlet temperature ${ }^{\circ} \mathrm{C}$ \\
\hline \multirow{2}{*}{$5 \#\left(2 \times 10^{4} \mathrm{~m}^{3}\right)$} & 16 日 8:00 & 10.27 & 11217 & 38.48 \\
\cline { 2 - 5 } & 17 日 8:00 & 9.75 & 10646 & 38.30 \\
\hline \multirow{2}{*}{ 6\# $\left(2 \times 10^{4} \mathrm{~m}^{3}\right)$} & 16 日 8:00 & 10.39 & 11349 & 44.20 \\
\cline { 2 - 5 } & 17 日 8:00 & 9.87 & 10778 & 43.09 \\
\hline \multirow{2}{*}{$7 \#\left(2 \times 10^{4} \mathrm{~m}^{3}\right)$} & 16 日 8:00 & 10.27 & 11217 & 45.73 \\
\cline { 2 - 5 } & 17 日 8:00 & 9.75 & 10646 & 45.70 \\
\hline \multirow{2}{*}{$8 \#\left(2 \times 10^{4} \mathrm{~m}^{3}\right)$} & 16 日 8:00 & 10.49 & 11349 & 46.01 \\
\cline { 2 - 5 } & 17 日 8:00 & 9.87 & 10778 & 46.06 \\
\hline \multirow{2}{*}{$9 \#\left(5 \times 10^{4} \mathrm{~m}^{3}\right)$} & 16 日 8:00 & 10.87 & 25019 & 38.34 \\
\cline { 2 - 5 } & 17 日 8:00 & 11.25 & 25928 & 50.99 \\
\hline \multirow{2}{*}{ 10\# $\left(5 \times 10^{4} \mathrm{~m}^{3}\right)$} & 16 日 8:00 & 10.87 & 24971 & 39.27 \\
\cline { 2 - 5 } & 17 日 8:00 & 11.23 & 25881 & 52.56 \\
\hline
\end{tabular}

\section{Energy Consumption Calculation results}

According to petroleum storage depots run data collected in the field, the establishment of model (1) - (18) is calculated to obtain the oil depot in continuous operation for 24 hours with the energy situation, and concrete results in table 4.

From the above results, for the study of petroleum storage depots, within 24 hours of running time, total energy efficiency of petroleum storage depots was $69.8 \%$, with a higher energy efficiency. The utilization of geothermal energy is $70 \%$ and higher than power utilization is $60.6 \%$. It indicates that the depot energy utilization efficiency is the higher, the heat loss is the less, and then it reflects higher operating efficiency furnace oil tanks, boilers and other equipment, tank insulation is good. Power utilization is relatively low, indicating that the low efficiency of the pump oil depots, to be further strengthened to improve pump efficiency will improve depot of crude power utilization and 
overall energy efficiency of the main aspects.

Table. 4 petroleum storage depots energy evaluation results

\begin{tabular}{c|c}
\hline project & Evaluation results \\
\hline Power of depot $(\mathrm{kw} . \mathrm{h})$ & 24843 \\
\hline Fuel gas consumption $\left(\mathrm{m}^{3}\right)$ & 28856.4 \\
\hline Energy efficiency $(\%)$ & 69.80 \\
\hline Utilization of geothermal energy $(\%)$ & 70.00 \\
\hline Power utilization $(\%)$ & 60.60 \\
\hline Unit turnover postal transmission power consumption $\left(\mathrm{kw} \cdot \mathrm{h} / 10^{4} \mathrm{t}\right)$ & 11419.21 \\
\hline Unit turnover oil consumption $\left(\mathrm{m}^{3} / 10^{4} \mathrm{t}\right)$ & 13263.99 \\
\hline Unit oil turnover comprehensive energy consumption $\left(\mathrm{kgce} / 10^{4} \mathrm{t}\right)$ & 25456.40 \\
\hline
\end{tabular}

\section{Conclusion}

According to the production process characteristics of crude oil transit depot, the transit crude oil process model to determine the major energy-using equipment of crude depot was established. The energy transfer process of depot was divided into energy transfer, energy conversion and energy utilization process. The energy utilization processes of different energy-using equipment were analyzed. According to the law of conservation and transformation of energy, a depot of crude oil transit energy balance equation is established. And we proposed six evaluation energy level depot indicators, including crude oil storehouse of energy efficiency, heat energy efficiency, electricity energy efficiency, power consumption unit oil turnover, turnover unit oil and gas consumption oil turnover unit comprehensive energy consumption of crude oil. Based on energy balance model and petroleum storage depots evaluation energy level established for the energy status of a petroleum storage depots were evaluated. The results shows that energy efficiency can reflect the overall energy utilization level of crude oil depot, oil depots pump efficiency is low resulting in low energy utilization the main reason is the weak link in energy depot.

\section{Acknowledgement}

This paper is Supported by PetroChina Innovation Foundation (2014D-5006-0607).

\section{References}

[1] Zhou Hailian power flow model and crude oil storage and transportation of energy analysis [D] Daqing: Northeast Petroleum University 2010.

[2] Yu Tao thermodynamic database crude energy system analysis [D] Daqing: Northeast Petroleum University 2011.

[3] Liu Erheng, Hua Ben associated oil storage and transportation system analysis of process parameters and energy optimization measures [J] Petrochemical Technology \& Application, 2009, 27 (5): 436 - 440.

[4] Li Dehai energy-saving heating oil depot research [D] Chengdu: Southwest Petroleum University 2004.

[5] Peng Guoqing energy consumption of crude oil storage tanks and control measures [J] Oil Pipeline, 2001, 20 (5): 49 to 52.

[6] Norikage color refinery oil tank to Reduce the consumption of [J] Applied Energy Technology, 
2007, (9): 14 to 16.

[7] Hu Wenhua, Li Jin reduce consumption of oil storage and transportation system [J] Portland Science and Technology, 1998, 9: 176 to 177. 